\title{
Investigations on white spot disease outbreak in Penaeus monodon (Fabricius, 1798) in association with Vibrio mimicus infection in the Sunderbans, West Bengal, India
}

\author{
R. ANANDA RAJA, A. PANIGRAHI, DEBASIS DE* AND SUJEET KUMAR \\ ICAR-Central Institute of Brackishwater Aquaculture, 75 Santhome high Road, R. A. Puram, Chennai - 600 028, India \\ "Kakdwip Research Centre of ICAR-Central Institute of Brackishwater Aquaculture, Kakdwip - 743347 \\ South 24 Parganas, West Bengal, India \\ e-mail: anandarajars@gmail.com
}

\begin{abstract}
The present study investigated the outbreak of white spot disease (WSD) in association with Vibrio mimicus infection, which occurred twice consecutively in a black tiger shrimp (Penaeus monodon) farm located in the Sunderbans, West Bengal, India. The farm stocked with post-larvae (PL)@16 PL m ${ }^{-2}$, encountered disease outbreak on the $41^{\text {st }}$ day of culture (DOC) followed by a second outbreak on the $54^{\text {th }}$ DOC with $100 \%$ mortality each time. Shrimp samples were collected for molecular diagnosis as well as for microbiological investigations. White spot syndrome virus (WSSV) infection was confirmed by polymerase chain reaction (PCR). V. mimicus isolated from the outbreak, was characterised by morphological, physiological and biochemical characteristics. V. mimicus isolated was found to be pathogenic by challenge studies which caused $100 \%$ mortality in P. monodon juveniles. Microbial load was studied in the natural infection and also in challenge trials in relation to the day of advancing infection. $\mathrm{LD}_{50}$ value for $V$. mimicus, isolated from the outbreak, was $10^{7.32}$ in P. monodon juveniles. Co-infection of $V$. mimicus with WSSV led to $100 \%$ mortality within seven days from the onset of clinical signs.
\end{abstract}

Keywords: Minimum inhibitory concentration, Vibriosis, Vibrio mimicus, White spot disease

\section{Introduction}

In the recent past, catastrophic outbreaks of white spot disease (WSD) in cultured penaeid shrimps wreaked havoc worldwide, especially in Asian countries. Cultured penaeid shrimp production decreased tremendously due to the outbreaks of WSD. WSD causing mass mortality was first reported in northern Taiwan during 1992 (Chou et al., 1995; Escobedo-Bonilla et al., 2008), followed by outbreaks in other countries. In India, it was first noticed in 1994 by Karunasagar et al. (1997). The etiological agent was identified as white spot syndrome virus (WSSV) belonging to a new viral genus Whispovirus under the family Nimaviridae (Mayo, 2002). The virus was found to be extremely virulent and cumulative mortality reached 80 to $100 \%$ within 3-7 days post-infection (Karunasagar et al., 1997). Such an outbreak of WSD, in association with vibriosis was noticed consecutively twice in a shrimp farm located in the Sunderbans, West Bengal and the present study reports the result of an investigation carried out during the outbreak.

\section{Materials and methods}

Shrimp pond details and sample collection

Shrimp culture with zero water exchange was followed in the farm with water depth not less than eight feet. Initial chlorination was done @20 ppm. The water

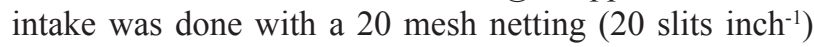
fixed at the foot valve of the pump and 80 and 100 mesh netting at the delivery points. The pond, covering an area of 0.48 ha, was stocked with black tiger shrimp, Penaeus monodon post-larvae (PL)@16 nos. $\mathrm{m}^{-2}$. Blind feeding was done twice a day with commercial pelleted feed up to $40^{\text {th }}$ day of culture (DOC), followed by four times a day (a) 10 to $3.5 \%$ of the body weight. The pond encountered disease outbreak on the $41^{\text {st }}$ DOC followed by a second outbreak on the $54^{\text {th }}$ DOC with $100 \%$ mortality each time. The average body weight (ABW) of the infected shrimp was recorded. About 10 shrimps, with signs of red colouration and white spots, were collected for five consecutive days from the first day of onset of clinical signs for PCR diagnosis as well as for microbiological investigations. Samples of pond water, sediment, shrimp muscle, haemolymph and hepatopancreas were collected aseptically for microbiological analyses. 


\section{Polymerase chain reaction $(P C R)$}

For two-step PCR amplification, four DNA oligonucleotide primers were used (Kimura et al., 1996). PCR was performed in a $25 \mu 1$ reaction mixture as reported by Ananda Raja et al. (2012a).

\section{Microbiological analyses}

In order to understand the microbial dynamics during the outbreak, total Vibrio count (TVC) and total plate count (TPC) were done for water, sediment, shrimp muscle, haemolymph and hepatopancreas samples for five consecutive days from the day of the clinical signs first observed (Biswas et al., 2012; Ananda Raja et al., 2014). All the procedures were done aseptically under laminar air flow. Initial bacterial isolation was done from the haemolymph and hepatopancreatic tissue. Predominant colonies observed on $1.5 \% \mathrm{NaCl}$ supplemented tryptone soya agar (TSA) plates were streak plated on to thiosulfate citrate bile salts sucrose (TCBS) agar plates. The predominant non-sucrose fermenting (green coloured) colonies grown on the TCBS plates were further screened and identified based on the phenotypic, physiological and biochemical characters according to Alsina and Blanch (1994).

\section{Minimum inhibitory concentration (MIC)}

The most dominant bacterial isolate (V18) was tested for the antimicrobial sensitivity and the MIC level was determined for 22 commercially available antimicrobial compounds using the HiComb strip (HiMedia). Single colony was inoculated to $1.5 \% \mathrm{NaCl}$ supplemented tryptone soya broth (TSB) and incubated at $30^{\circ} \mathrm{C}$ for $3 \mathrm{~h}$. Optical density (OD) value was recorded at $625 \mathrm{~nm}$ and the plate count was determined per $\mathrm{ml}$ of broth. The turbidity was compared between the bacterial suspension and McFarland 0.5 standard prepared by mixing $0.5 \mathrm{ml}$ of $1.175 \%$ barium chloride and $99.5 \mathrm{ml}$ of $0.36 \mathrm{~N}$ sulfuric acid $\left(10^{5}-10^{6}\right.$ cells $\left.\mathrm{ml}^{-1}\right)$. Any increase or decrease in turbidity to the standard was adjusted either by adding sterile normal saline (NS) or by further incubating the inoculum. Then, the bacterial suspension was inoculated on to Muller Hinton Agar (MHA) plates, using sterile non-toxic cotton swabs. The plates were dried for 10 min before placing the HiComb strips. Strips containing 22 antibacterial agents such as ampicillin, amoxycillin, amoxyclav, nalidixic acid, enrofloxacin, ciprofloxacin, norfloxacin, kanamycin, streptomycin, noemycin, gentamicin, vancomycin, chloramphenicol, erythromycin, tetracycline, oxytetracycline, chlortetracycline, metronidazole, furazolidone, sulphafurazole, co-trimoxazole and trimethoprim were placed on the MHA plates individually and incubated at $30^{\circ} \mathrm{C}$ for $18 \mathrm{~h}$. After incubation, the diameter of the zone of inhibition was measured and interpreted as per the zone diameter interpretative chart (HiMedia). The sensitivity of the isolates to the antibiotics was determined accordingly when the zone of inhibition equaled $8 \mathrm{~mm}$.

Pathogenicity and $\mathrm{LD}_{50}$

Hatchery produced PCR screened healthy juveniles of $P$. monodon were procured and maintained (a) 10 shrimps per tank in 501 glass aquaria with pre-treated water at $30 \pm 1{ }^{\circ} \mathrm{C}$ with $7-8 \%$ salinity. The weight and length of each shrimp were recorded. A slant culture of the bacterial isolate (V18) stored at $4^{\circ} \mathrm{C}$ was sub-cultured, and an $18 \mathrm{~h}$ shake culture was centrifuged at $4800 \mathrm{~g}$ for $15 \mathrm{~min}$. The cell pellets were washed twice using normal saline (NS). The shrimps were challenged by intramuscular injection of $10^{4}$ to $10^{8}$ colony forming units (cfu) in $50 \mu \mathrm{lNS}$ per shrimp in the ventral side of each shrimp, between II and III abdominal segments. The same quantity of NS alone was injected to the control groups. Clinical signs and mortality pattern were observed every 15 min during the first hour post-injection (hpi) followed by every $1 \mathrm{~h}$ until $6 \mathrm{hpi}$. The experiment was continued for seven days and the animals were monitored every $12 \mathrm{~h}$ (Joseph Selvin and Lipton, 2003). Parameters such as $\mathrm{pH}$, temperature and salinity were recorded thrice a day for seven days. Tissue homogenate of moribund shrimp hepatopancreas was used for re-isolation of bacteria using Zobell marine agar (ZMA) plates to prove Koch's postulates. $\mathrm{LD}_{50}$ value was calculated as per Reed and Muench (1938).

Statistical analyses

The data were analysed with independent samples t-test, one way ANOVA and Duncan's multiple range test (DMRT) using SPSS for Windows v.17.0 programme (SPSS Inc. 2007). Results were expressed as mean \pm standard error (SE).

\section{Results and discussion}

Average body weight (ABW) of the infected shrimps was $6.44 \pm 0.15$ and $8.12 \pm 0.10 \mathrm{~g}$ at $41^{\text {st }}$ and $54^{\text {th }}$ DOC, respectively. The major clinical signs such as lethargy, loss of balance, preening and no response to stimulus, reduced feeding, presence of white spots initially on the carapace which later progressed to the whole body, reddish discolouration, dark necrotic spots and finally death (Wongteerasupaya et al., 1995, Tan et al., 2001; Wu et al., 2001) were observed during the outbreak. PCR analyses showed that the shrimp samples were I and II step positive for WSSV (Fig. 1, 2). Lo et al. (1998) reported that the WSSV infected shrimps with white spots lesions might survive indefinitely under non-stressful conditions. In addition, Ananda Raja et al. (2012b) reported that the 


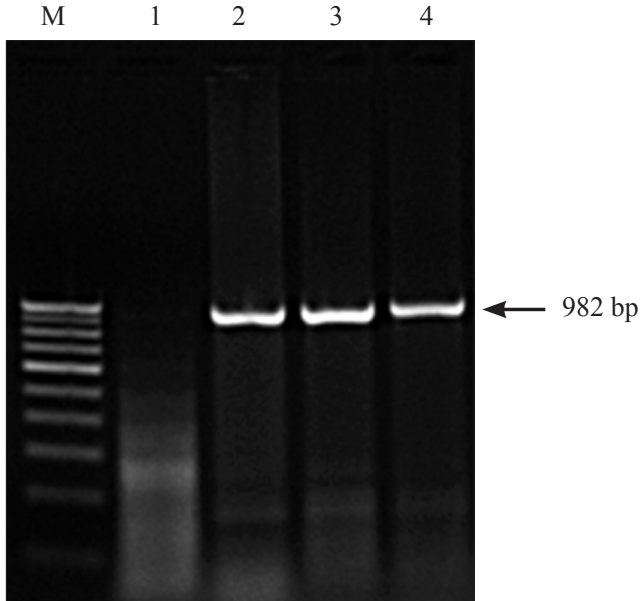

M:100 bp ladder; Lane 1: Negative control; Lane 2: Positive control; Lane 3 \& 4: Shrimp positive

Fig. 1. Gel picture of It step PCR for WSSV

animals were apparently healthy with no clinical signs and lesions though they harbour I step PCR positive viral load. But in the present study, the animals were I step PCR positive in association with Vibrio infection which led to the stress and disease outbreak.

The microbial load in pond water, sediment, muscle, haemolymph and hepatopancreas were found increasing significantly as days advanced and significant increase in gross lesions was noticed (Table 1,2). Significant difference $(p<0.01)$ was observed in the TVC and TPC of the water, sediment, muscle, haemolymph and hepatopancreas (Table 3), but, from the $\mathrm{LD}_{50}$ trials, only TVC was statistically significant $(p<0.05)$. Based on morphological, physiological and biochemical

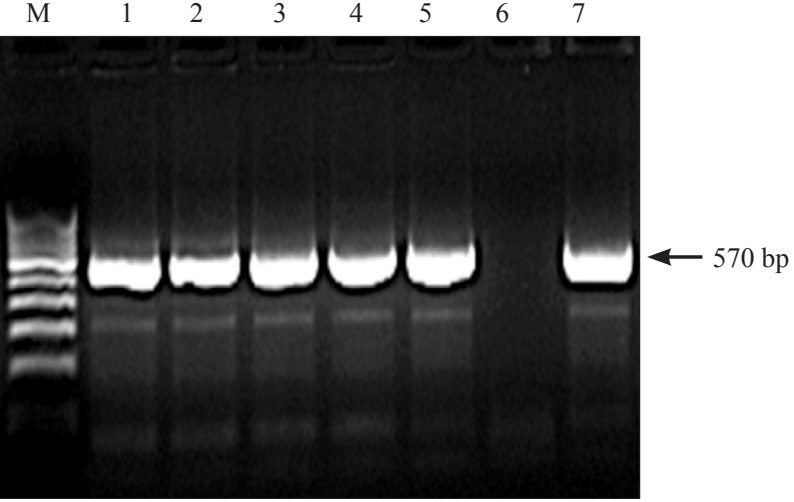

M:100 bp ladder; Lane 1 to 5: Shrimp positive; Lane 6: Negative control; Lane 7: Positive control

Fig. 2. Gel picture of $2^{\text {nd }}$ step PCR for WSSV

characteristics (Alsina and Blanch, 1994), it was confirmed that all the shrimp were infected with a single type of bacterium, Vibrio mimicus (V18). In addition, all the 50 shrimps collected for five consecutive days showed characteristic lesions of WSD and this was confirmed by PCR. Therefore, the co-infection of $V$. mimicus and WSSV in the pond was ascertained. Four species of bacteria viz., Vibrio alginolyticus, $V$. parahaemolyticus, $V$. anguillarum and Pseudomonas aeruginosa were so far reported, in association with WSD in shrimps (Jayasree et al., 2000, Joseph Selvin and Lipton, 2003; Liu et al., 2004). Results of the present study showed that $V$. mimicus infection can also cause severe mortality in association with WSD. In addition, it was observed that the isolate was highly susceptible to enrofloxacin, ciprofloxacin, norfloxacin, vancomycin, chloramphenicol and trimethoprim and susceptible to amoxycillin, nalidixic acid, kanamycin,

Table 1. Percentage of gross lesions observed from the day 1 to 5 of the disease outbreak

\begin{tabular}{|c|c|c|c|c|}
\hline Days after initial sign & White spot ${ }^{* *}$ & Reddish discoloration ${ }^{* *}$ & Dark necrotic spots ${ }^{* *}$ & No lesion ${ }^{* *}$ \\
\hline 1 & $14.72 \pm 1.43^{\mathrm{a}}$ & $0.85 \pm 0.42^{\mathrm{a}}$ & $4.75 \pm 1.12^{\mathrm{a}}$ & $79.68 \pm 1.40^{\mathrm{a}}$ \\
\hline 2 & $21.43 \pm 0.84^{\mathrm{b}}$ & $1.04 \pm 0.64^{\mathrm{a}}$ & $8.76 \pm 1.68^{\mathrm{ab}}$ & $68.77 \pm 2.28^{b}$ \\
\hline 3 & $26.51 \pm 0.46^{\mathrm{b}}$ & $3.46 \pm 0.45^{b}$ & $10.89 \pm 1.14^{\mathrm{b}}$ & $59.14 \pm 0.64^{\mathrm{c}}$ \\
\hline 4 & $37.25 \pm 0.90^{\mathrm{c}}$ & $5.09 \pm 0.83^{\mathrm{bc}}$ & $17.35 \pm 1.14^{\mathrm{c}}$ & $40.31 \pm 1.07^{\mathrm{d}}$ \\
\hline 5 & $52.75 \pm 3.13^{\mathrm{d}}$ & $6.78 \pm 0.18^{\mathrm{c}}$ & $25.98 \pm 2.35^{\mathrm{d}}$ & $14.49 \pm 5.63^{\mathrm{e}}$ \\
\hline
\end{tabular}

${ }^{* *} \mathrm{p}<0.01$, Values bearing different superscripts in a column differ significantly

Table 2. Total plate count (TPC) and total Vibrio count (TVC) in WSSV and Vibrio mimicus infected shrimp monoculture ponds for five consecutive days

\begin{tabular}{|c|c|c|c|c|c|c|c|c|c|}
\hline \multicolumn{2}{|c|}{ Water } & \multicolumn{2}{|c|}{ Sediment } & \multicolumn{2}{|c|}{ Muscle } & \multicolumn{2}{|c|}{ Haemolymph } & \multicolumn{2}{|c|}{ Hepatopancreas } \\
\hline $\begin{array}{l}\text { ТPC } \\
\left(10^{6} \mathrm{cfu} \mathrm{m}^{-1}\right)^{* *}\end{array}$ & $\begin{array}{l}\text { TVC } \\
\left(10^{5} \mathrm{cfu} \mathrm{ml}^{-1}\right)^{*}\end{array}$ & $\begin{array}{l}\text { ТPC } \\
\left(10^{6} \mathrm{cfu} \mathrm{m}^{-1}\right)^{* *}\end{array}$ & $\begin{array}{l}\text { TVC } \\
\left(10^{5} \mathrm{cfu} \mathrm{ml}^{-1}\right)^{* *}\end{array}$ & $\begin{array}{l}\text { ТPC } \\
\left(10^{6} \mathrm{cfu} \mathrm{ml}^{-1}\right)^{* *}\end{array}$ & $\begin{array}{l}\text { TVC } \\
\left(10^{5} \mathrm{cfu} \mathrm{ml}^{-1}\right)^{* *}\end{array}$ & $\begin{array}{l}\text { ТPC } \\
\left(10^{6} \mathrm{cfu} \mathrm{ml}^{-1}\right)^{* *}\end{array}$ & $\begin{array}{l}\text { TVC } \\
\left(10^{5} \mathrm{cfu} \mathrm{m}^{-1}\right)^{*}\end{array}$ & $\begin{array}{l}\text { ТPC } \\
\left(10^{6} \mathrm{cfu} \mathrm{ml}^{-1}\right)^{* *}\end{array}$ & $\begin{array}{l}\text { TVC } \\
\left(10^{5} \mathrm{cfu} \mathrm{ml}^{-1}\right)^{*}\end{array}$ \\
\hline $0.49 \pm 0.02^{\mathrm{a}}$ & $0.16 \pm 0.01^{\mathrm{a}}$ & $28.84 \pm 1.14^{\mathrm{a}}$ & $13.58 \pm 0.3^{\mathrm{a}}$ & $0.21 \pm 0.01^{\mathrm{a}}$ & $0.003 \pm 00^{\mathrm{a}}$ & $3.63 \pm 0.22^{\mathrm{a}}$ & $2.17 \pm 0.05^{\mathrm{a}}$ & $62.25 \pm 1.3^{\mathrm{a}}$ & $19.98 \pm 0.6^{\mathrm{a}}$ \\
\hline $1.03 \pm 0.003^{b}$ & $0.19 \pm 0.01^{\mathrm{a}}$ & $31.0 \pm 1.2^{\mathrm{a}}$ & $19.38 \pm 0.4^{\mathrm{b}}$ & $0.29 \pm 0.01^{\mathrm{a}}$ & $0.004 \pm 00^{\mathrm{a}}$ & $5.00 \pm 0.16^{\mathrm{b}}$ & $3.50 \pm 0.02^{\mathrm{b}}$ & $86.75 \pm 4.8^{b}$ & $18.83 \pm 3.4^{\mathrm{a}}$ \\
\hline $1.44 \pm 0.07^{\mathrm{c}}$ & $0.24 \pm 0.01^{\mathrm{b}}$ & $51.0 \pm 1.8^{\mathrm{b}}$ & $22.23 \pm 1.1^{\mathrm{c}}$ & $1.54 \pm 0.05^{\mathrm{b}}$ & $0.008 \pm 00^{\mathrm{b}}$ & $5.43 \pm 0.14^{b}$ & $4.52 \pm 0.04^{\mathrm{c}}$ & $133.25 \pm 4.8^{\mathrm{c}}$ & $25.10 \pm 1.2^{\mathrm{ab}}$ \\
\hline $2.07 \pm 0.07^{\mathrm{d}}$ & $0.28 \pm 0.02^{\mathrm{c}}$ & $87.13 \pm 2.4^{\mathrm{c}}$ & $27.6 \pm 0.7^{\mathrm{d}}$ & $2.08 \pm 0.08^{\mathrm{c}}$ & $0.01 \pm 00^{c}$ & $7.34 \pm 0.18^{c}$ & $5.83 \pm 0.05^{\mathrm{d}}$ & $187.25 \pm 7.3^{\mathrm{d}}$ & $28.15 \pm 1.2^{\mathrm{b}}$ \\
\hline $2.62 \pm 0.07^{\mathrm{e}}$ & $0.30 \pm 0.003^{\mathrm{c}}$ & $117.13 \pm 10.1^{\mathrm{d}}$ & $29.55 \pm 0.3^{\mathrm{d}}$ & $2.38 \pm 0.01^{\mathrm{d}}$ & $0.01 \pm 00^{\mathrm{c}}$ & $8.94 \pm 0.02^{\mathrm{d}}$ & $6.97 \pm 0.02^{\mathrm{e}}$ & $222.5 \pm 6.5^{\mathrm{e}}$ & $28.83 \pm 0.9^{b}$ \\
\hline
\end{tabular}

${ }^{*} \mathrm{p}<0.05 ;{ }^{* *} \mathrm{p}<0.01$, Values bearing different superscripts in a column differ significantly 
Table 3. Total plate count (TPC) and total Vibrio count (TVC) in shrimp monoculture ponds infected with WSSV and Vibrio mimicus, and in the $\mathrm{LD}_{50}$ experiment (V. mimicus) tanks

\begin{tabular}{|c|c|c|c|c|c|}
\hline Count & Water & Sediment & Muscle & Haemolymph & Hepatopancreas \\
\hline \multicolumn{6}{|l|}{ Pond } \\
\hline TPC $\left(10^{6} \mathrm{cfu} \mathrm{ml}^{-1}\right)^{* *}$ & $1.53 \pm 0.38^{\mathrm{a}}$ & $63.02 \pm 17.1^{\mathrm{b}}$ & $1.3 \pm 0.45^{\mathrm{a}}$ & $6.20 \pm 0.90^{\mathrm{a}}$ & $138.40 \pm 29.96^{c}$ \\
\hline $\operatorname{TVC}\left(10^{5} \mathrm{cfu} \mathrm{ml}\right)^{* *}$ & $0.23 \pm 0.03^{\mathrm{a}}$ & $22.47 \pm 2.87^{\mathrm{b}}$ & $0.007 \pm 0.002^{\mathrm{a}}$ & $4.62 \pm 0.85^{\mathrm{a}}$ & $24.18 \pm 2.06^{\mathrm{b}}$ \\
\hline \multicolumn{6}{|l|}{$\mathrm{LD}_{50}$ trial } \\
\hline TPC $\left(10^{6} \mathrm{cfu} \mathrm{ml}^{-1}\right)$ & $236.94 \pm 191.77$ & - & $13.37 \pm 4.03$ & $5.93 \pm 0.97$ & $420.1 \pm 171.10$ \\
\hline $\operatorname{TVC}\left(10^{5} \mathrm{cfu} \mathrm{m} \mathrm{m}^{-1}\right)^{*}$ & $2.76 \pm 1.78^{\mathrm{a}}$ & - & $9.84 \pm 2.22^{\mathrm{a}}$ & $4.57 \pm 0.84^{\mathrm{a}}$ & $404.93 \pm 237.95^{\mathrm{b}}$ \\
\hline
\end{tabular}

${ }^{*} \mathrm{p}<0.05 ;{ }^{* *} \mathrm{p}<0.01$, Values bearing different superscripts in a row differ significantly

streptomycin, neomycin, gentamicin, erythromycin, tetracycline, oxytetracycline, metronidazole, furazolidone, sulphafurazole and co-trimoxazole. The isolate was resistant to $\beta$-lactam antibiotics, such as ampicillin and amoxyclav (Table 4). No unusual resistance was observed with 22 antimicrobials, as observed by Manjusha et al. (2005).

The total length and weight of juvenile shrimp used for the challenge trials with the $V$. mimicus isolate (V18) ranged between $83.3 \pm 1.32$ and $85.1 \pm 1.08 \mathrm{~mm}$ and $5.20 \pm 0.60$ and $5.40 \pm 0.10 \mathrm{~g}$, respectively. Parameters such as $\mathrm{pH}$, temperature and salinity recorded during the experiment were: $7.9 \pm 0.02, \quad 30.5 \pm 0.31^{\circ} \mathrm{C}$ and $7.5 \pm 0.02 \mathrm{~g} \mathrm{l}^{-1}$, respectively. All shrimps died at 6 to 24 hpi with a high dose of $10^{8}$ cfu per shrimp. But, no mortality was observed within 7 days post-infection (dpi) at $10^{5}$ cfu per shrimp, though Vibrio infection was noticed on 5 dpi. Based on this observation, the $\mathrm{LD}_{50}$ value was

Table 4. Minimum inhibitory concentration (MIC) of V18 to different antimicrobial compounds

\begin{tabular}{lll}
\hline Antibiotics group & Antibiotics & MIC $(\mu \mathrm{g})$ \\
\hline$\beta$-Lactam antibiotics & Ampicillin & $>256$ \\
& Amoxycillin & $<0.01$ \\
Fluoroquinolones/Quinolones & Amoxyclav & $>240$ \\
& Nalidixic acid & 0.05 \\
& Enrofloxacin & $<0.001$ \\
& Ciprofloxacin & $<0.001$ \\
Aminoglycosides & Norfloxacin & $<0.001$ \\
& Kanamycin & 3 \\
& Streptomycin & 7.5 \\
& Noemycin & 1 \\
Glycopeptides & Gentamicin & 5 \\
Macrolides & Vancomycin & $<0.001$ \\
Tetracyclines & Chloramphenicol & $<0.001$ \\
& Erythromycin & 0.01 \\
& Tetracycline & 0.25 \\
Nitroimidazole & Oxytetracycline & 0.5 \\
Nitrofurans & Chlortetracycline & 0.5 \\
Sulphanomides & Metronidazole & 40 \\
& Furazolidone & 5 \\
& Sulphafurazole & 0.01 \\
& Co-Trimoxazole & 0.05 \\
& Trimethoprim & $<0.001$ \\
\hline
\end{tabular}

found to be $10^{7.32} \mathrm{cfu}$ per shrimp. Signs of infection among the challenged animals included lethargy, lack of food intake, empty midgut, abnormal swimming behaviour, brown to black spots on the shell, pink or brown gills, reddish discolouration, murky whitish muscle, flexure of the abdominal musculature, folded tail base and dark necrotic areas in the tail fan (NIO, 1998). As per the earlier reports, lower stocking density, good management practices and stress free environment, even in presence of WSSV infection could lead to successful grow-out culture (Ananda Raja et al., 2012b). Present study revealed that co-infection of $V$. mimicus with WSSV can lead to $100 \%$ mortality within seven days from the onset of clinical signs. Moreover it was confirmed that the $V$. mimicus isolate was also pathogenic which could cause 100\% mortality in P. monodon juveniles.

\section{Acknowledgements}

The authors are immensely thankful to the Director, ICAR-Central Institute of Brackishwater Aquaculture (ICAR-CIBA), Chennai and the Officer-in-charge, Kakdwip Research Centre, Kakdwip, West Bengal, India for providing valuable guidance.

\section{References}

Alsina, M. and Blanch, A. R. 1994. A set of keys for biochemical identification of environmental Vibrio species, J. Applied Bacteriol., 76: 79-85. doi: 10.1111/j.1365-2672.1994. tb04419.x

Ananda Raja, R., Kalaimani, N., Panigrahi, A. and Ponniah, A. G. 2014. Effect of season and treatment of seed with antibiotics on growout culture of Penaeus monodon (Fabricius, 1798) at Sunderban, India. Turkish J. Fish. Aquat. Sci., 14: 879-885. doi: 10.4194/1303-2712-v14_4_05.

Ananda Raja, R., Sujeet Kumar, Sundaray, J. K., De, D., Biswas, G. and Ghoshal, T. K. 2012a. Haematological parameters in relation to sex, morphometric characters and incidence of white spot syndrome virus in tiger shrimp Penaeus monodon Fabricius, 1798 from Sunderban, West Bengal. Indian J. Fish., 59(4): 169-174.

Ananda Raja, R., Panigrahi, A. and Sujeet Kumar 2012b. Epidemiological investigation of brackishwater 
culture systems in West Bengal, India, J. Appl. Aquac., 24(1): 49-59. doi: 10.1080/10454438.2012.652029.

Biswas, G., Ananda Raja, R., De, D., Sundaray, J. K., Ghoshal, T. K., Anand, S., Kumar, S., Panigrahi, A., Thirunavukkarasu, A. R. and Ponniah, A. G. 2012. Evaluation of productions and economic returns from two brackishwater polyculture systems in tide-fed ponds. J. Appl. Ichthyol., 28:116-122. doi: 10.1111/j.1439-0426. 2011.01909.x.

Chou, H. Y., Huang, C. Y., Wang, C. H., Chiang, H. C. and Lo, C. F. 1995. Pathogenicity of a baculovirus infection causing white spot syndrome in cultured penaeid shrimp in Taiwan. Dis. Aquat. Org., 23: 165-173.

Escobedo-Bonilla, C. M., Alday-Sanz, V., Wille, M., Sorgeloos, P., Pensaert, M. B. and Nauwynck, H. J. 2008. A review on the morphology, molecular characterisation, morphogenesis and pathogenesis of white spot syndrome virus. J. Fish Dis., 31: 1-18.

Jayasree, L., Janakiram, P. and Madhavi, R. 2000. Characteristics, pathogenicity and antibiotic sensitivity of bacterial isolates from white spot diseased shrimp. Asian Fish. Sci., 13: 327-334.

Joseph Selvin and Lipton, A. P. 2003. Vibrio alginolyticus associated with white spot disease of Penaeus monodon. Dis. Aquat. Org., 57: 147-150.

Karunasagar, I., Otta, S. K. and Karunasagar, I. 1997. Histopathological and bacteriological study of white spot syndrome of Penaeus monodon along the west coast of India. Aquaculture, 153: 9-13. doi: 10.1016/S0044-8486 (97)00011-2.

Kimura, T., Yamano, K., Nakano, H., Monoyama, K., Hiraoka, M. and Frousp, K. 1996. Detection of penaeid rod shaped DNA (PRVD) by PCR (in Japanese). Fish Pathol., 31: 93-98.

Liu, C. H., Cheng, W., Hsu, J. P. and Chen, J. C. 2004. Vibrio alginolyticus infection in the white shrimp Litopenaeus vannamei confirmed by polymerase chain reaction and 16S rDNA sequencing. Dis. Aquat. Org., 61: 169-174.

Lo, C. F., Chang, Y. S., Cheng, C. T. and Kou, G. H. 1998. PCR monitoring of cultured shrimp for white spot syndrome virus (WSSV) infection in growout ponds. In: Flegel, T. W. (Ed.), Advances in shrimp biotechnology. National Centre for Genetic Engineering and Biotechnology, Bangkok, p. 281-286.

Manjusha, S., Sarita, G. B., Elyas, K. K. and Chandrasekaran, M. 2005. Multiple antibiotic resistances of Vibrio isolates from coastal and brackishwater areas. Amer. J. Biochem. Biotechnol., 1(4): 201-206. doi: 10.3844/ ajbbsp.2005.193.198.

Mayo, M. A. 2002. A summary of taxonomic changes recently approved by ICTV. Achie. Virol., 147: 1655-1656.

NIO 1998. Diseases in grow-out ponds. Bioinformatics Centre, National Institute of Oceanography, Dona Paula, Goa, India.

Reed, L. J. and Muench, H. 1938. A simple method of estimating fifty percent endpoints. Amer. J. Hyg., 27: 493-497.

Tan, L. T., Soon, S., Lee, K. L., Shariff, M., Hassan, M. D. and Omar, A. R. 2001. Quantitative analysis of an experimental white spot syndrome virus (WSSV) infection in Penaeus monodon Fabricius using competitive polymerase chain reaction. J. Fish Dis., 24: 315-323.

Wongteerasupaya, C., Vickers, J. E., Sriurairatana, S., Nash, G. L., Alarajamorn, A., Boonsaeng, V., Panyim, S., Tassanakajon, A., Withyachumnarkul, B. and Flegel, T. W. 1995. A non-occluded, systemic baculovirus that occurs in cells of ectodermal and mesodermal origin and causes high mortality in the black tiger prawn Penaeus monodon. Dis. Aquat. Org., 21: 69-77.

Wu, J. L., Namikoshi, A., Nishizawa, T., Mushiake, K., Teruya, K. and Muroga, K. 2001. Effects of shrimp density on transmission of penaeid acute viremia in Penaeus japonicus by cannibalism and the waterborne route. Dis. Aquat. Org., 47: 129-135.

Date of Receipt $\quad$ : 05.01.2016

Date of Acceptance : 27.02 .2017 